\section{Case Reports in Gastroenterology}

Case Rep Gastroenterol 2017;11:23-28

DOI: $10.1159 / 000452735$

Publisned onimne: January 27, 2017 (c) 2017 The Author(s)

Published by S. Karger AG, Basel www.karger.com/crg

This article is licensed under the Creative Commons Attribution-NonCommercial 4.0 International License (CC BY-NC) (http://www.karger.com/Services/OpenAccessLicense). Usage and distribution for commercial purposes requires written permission.

\title{
Black Cohosh Hepatotoxicity with Autoimmune Hepatitis Presentation
}

\author{
Diana L. Franco $^{a} \quad$ Santosh Kale ${ }^{b}$ Dora M. Lam-Himlin ${ }^{c}$ \\ M. Edwyn Harrison ${ }^{\text {d }}$ \\ ${ }^{a}$ Gastroenterology Fellow, Mayo Clinic, Scottsdale, AZ, USA; ${ }^{b}$ Bankura Sammilani Medical \\ College, Bankura, India; ${ }^{C}$ Department of Pathology and Laboratory Medicine, Mayo Clinic, \\ Scottsdale, AZ, USA; ${ }^{d}$ Division of Gastroenterology and Hepatology, Mayo Clinic, \\ Scottsdale, AZ, USA
}

\section{Keywords}

Black cohosh · Hepatotoxicity · Autoimmune hepatitis presentation

\section{Abstract}

Herbal medicines have been used for the treatment of various ailments since time immemorial. Black cohosh $(B C)$ is well known for the treatment of postmenopausal symptoms, with conflicting evidence supporting its safety and benefits. We present a rare case of $\mathrm{BC}$-induced autoimmune hepatitis (AIH) with hepatotoxicity in a 69-year-old female. To our knowledge, this represents the third case of $\mathrm{BC}$-induced $\mathrm{AIH}$.

(C) 2017 The Author(s)

Published by S. Karger AG, Basel

\section{Introduction}

Vasomotor symptoms are the cardinal symptoms of menopause, affecting more than three-quarters of midlife women. Nonprescription therapies include dietary isoflavones, vitamin E, and herbal remedies like black cohosh (BC) and Chinese herbs. BC (Actaea racemosa or Cimicifuga racemosa) is most widely used among the herbal preparations. Although 


\section{Case Reports in \\ Gastroenterology}

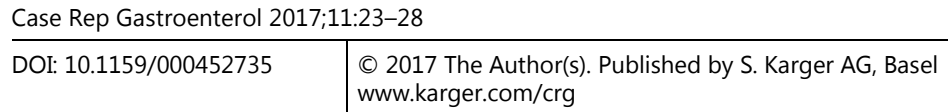

Franco et al.: Black Cohosh Hepatotoxicity with Autoimmune Hepatitis Presentation

adverse events following the use of $\mathrm{BC}$ are infrequent, there are various literature reports of its adverse effects, ranging from liver failure to a weak correlation with hepatitis [1-4].

We present a rare case of $\mathrm{BC}$-induced liver injury with autoimmune hepatitis (AIH) presentation following the 1-week use of over-the-counter $\mathrm{BC}$ for hot flashes. Based on the causality assessment algorithm of the Council for International Organizations of Medical Sciences (CIOMS), it fell into the highly probable category of drug-induced liver injury, whereas the liver biopsy with elevated serum markers confirmed its autoimmune nature. Other potential causes of liver injury such as biliary obstruction, viral hepatitis, hemochromatosis, or Wilson's disease were ruled out with appropriate tests.

\section{Case Report}

A 69-year-old female with a past medical history of hypertension and a remote history of hepatitis A infection presented to our institution with a 2-week history of sharp right upper quadrant pain and a 3-day history of dark urine and clay-colored stools. Her medications included amlodipine, metoprolol, and omeprazole, which she had been taking for years, and $150 \mathrm{mg}$ of BC a day (root standardized extract) for her hot flashes, started 1 week prior to the onset of her symptoms. She denied any alcohol use, and her family history was negative for liver disease or autoimmune diseases.

Vital signs were within normal limits. Physical examination was significant for tenderness in the right upper quadrant and jaundice without any stigmata of chronic liver disease. On admission, liver function tests (LFTs) were elevated, with total bilirubin $6.3 \mathrm{mg} / \mathrm{dL}$, direct bilirubin $4.9 \mathrm{mg} / \mathrm{dL}$, alkaline phosphatase $296 \mathrm{IU} / \mathrm{L}$, alanine transaminase 2,385 IU/L, and aspartate transaminase 1,386 IU/L; LFTs had been normal 1 year before. She had normal liver synthetic function with an international normalized ratio of 1 and albumin of $4.3 \mathrm{~g} / \mathrm{dL}$. Magnetic resonance imaging of the abdomen was unremarkable. Further evaluation was negative for acetaminophen level, urine drug screen, viral hepatitis panel, ceruloplasmin protein electrophoresis, and genetic testing for hemochromatosis. The autoimmune panel revealed elevated anti-nuclear antibody and anti-smooth muscle antibody (Table 1). Liver biopsy showed intense portal-based chronic inflammation with prominent plasma cell population and moderate lobular activity without necrosis or fibrosis, findings consistent with AIH (Fig. 1, Fig. 2).

BC was discontinued upon admission. Given the autoimmune pattern on biopsy, prednisone and azathioprine were started at a dose of 30 and $50 \mathrm{mg}$ a day, respectively. Two days after the start of treatment and 5 days after the discontinuation of BC, LFTs started to decrease, with complete normalization after 3 months of treatment. Prednisone was discontinued after 3 months, followed by discontinuation of azathioprine after 6 months. The patient's LFTs remained normal after 1 year of follow-up without treatment.

\section{Discussion}

$\mathrm{BC}$ is a flowering plant native to Canada and the eastern United States. Its root has been used since time immemorial by the native Indian population for the treatment of postmeno- 
pausal symptoms. Triterpene glycosides along with other phenolic constituents are believed to be the active ingredients [5]. Recent studies have shown conflicting evidence regarding its safety and efficacy $[4,6]$.

Extracts from BC are thought to possess an estrogen-like component potentially helping in vasomotor symptoms in menopausal women [7]. In 2014, Enbom et al. [8] demonstrated that the mechanism of hepatotoxicity through $\mathrm{BC}$ is due to the oxidative damage of the liver cells caused by the accumulation of protein adducts which serve as autoantigens and provoke an autoimmune response.

Causality assessment is a major clinical challenge, since temporal associations are not sufficient. Causality assessment may be achieved by a variety of algorithms. The CIOMS proposes a structured causality assessment algorithm that gives points to establish causality for drug-induced liver injury [9]. A score $>6$ makes the drug "probable" for inducing liver toxicity, and a score $>8$ makes the drug "highly probable" for causing hepatotoxicity. In our case, the causality assessment score was 10 points (Table 2).

There have been previous reports of $\mathrm{BC}$ hepatotoxicity; however, lack of basic information, such as on timing and comedication, interferes with causality assessment. In a review by Teschke et al. [4], 69 cases of reported BC toxicity were analyzed by causality algorithms. Only 1 case had "probable" BC-induced toxicity, with the remaining cases labeled as having confounding variables, such as use of herbal mixtures with multiple ingredients, missing temporal association between $\mathrm{BC}$ use and development of liver disease, and preexisting liver diseases.

Drug-induced AIH (DIAIH) occurs due to immune response against the protein adducts formed within the liver, where they bind to cellular proteins and behave as autoantigens [10]. Drugs like minocycline and nitrofurantoin are some of the well-known causes of DIAIH, whereas BC-induced AIH has been reported in only 2 previous case reports [2,11]. DIAIH is suspected in the presence of AIH with concurrent drug use, which was the case with our patient [12]. Liver biopsy along with serological markers helps to confirm the diagnosis. Interface hepatitis, usually associated with plasma cells, is an important finding. Autoantibodies are helpful, but not completely reliable, for the severity and the course [13, 14].

Our patient did not have the usual course for AIH, since she responded unusually rapidly to immunosuppressive therapy and has not relapsed after relatively early and complete withdrawal of therapy. To our knowledge, this is the first case of highly probable druginduced injury as defined by formal scores and presenting with AIH.

In conclusion, hepatotoxicity causality assessment is a major clinical challenge, since temporal associations are not sufficient. The reported cases lack basic information, which interferes with causality assessment as it is not considered valid. Stricter FDA and governmental regulations need to be applied to the purity of herbal remedies like $\mathrm{BC}$, as serious adverse effects like DIAIH can be seen.

\section{Statement of Ethics}

The authors have no ethical conflicts to disclose. 


\section{Case Reports in Gastroenterology}

Case Rep Gastroenterol 2017;11:23-28

(C) 2017 The Author(s). Published by S. Karger AG, Basel www.karger.com/crg

\section{Disclosure Statement}

The authors have no conflicts of interest to disclose.

\section{References}

1 Lontos S, Jones RM, Angus PW, Gow PJ: Acute liver failure associated with the use of herbal preparations containing black cohosh. Med J Aust 2003;179:390-391.

-2 Guzman G, Kallwitz ER, Wojewoda C, Chennuri R, Berkes J, Layden TJ, Cotler SJ: Liver injury with features mimicking autoimmune hepatitis following the use of black cohosh. Case Rep Med 2009;2009:918156.

Pierard S, Coche JC, Lanthier P, Dekoninck X, Lanthier N, Rahier J, Geubel AP: Severe hepatitis associated with the use of black cohosh: a report of two cases and an advice for caution. Eur J Gastroenterol Hepatol 2009;21:941-945. Teschke R, Bahre R, Genthner A, Fuchs J, Schmidt-Taenzer W, Wolff A: Suspected black cohosh hepatotoxicity - challenges and pitfalls of causality assessment. Maturitas 2009;63:302-314.

5 Nuntanakorn P, Jiang B, Einbond LS, Yang H, Kronenberg F, Weinstein IB, Kennelly EJ: Polyphenolic constituents of Actaea racemosa. J Nat Prod 2006;69:314-318.

6 Shams T, Setia MS, Hemmings R, McCusker J, Sewitch M, Ciampi A: Efficacy of black cohosh-containing preparations on menopausal symptoms: a meta-analysis. Altern Ther Health Med 2010;16:36-44. Ruhlen RL, Sun GY, Sauter ER: Black cohosh: insights into its mechanism(s) of action. Integr Med Insights 2008;3:21-32.

Enbom ET, Le MD, Oesterich L, Rutgers J, French SW: Mechanism of hepatotoxicity due to black cohosh (Cimicifuga racemosa): histological, immunohistochemical and electron microscopy analysis of two liver biopsies with clinical correlation. Exp Mol Pathol 2014;96:279-283. Teschke R, Schwarzenboeck A, Hennermann KH: Causality assessment in hepatotoxicity by drugs and dietary supplements. Br J Clin Pharmacol 2008;66:758-766. Liu ZX, Kaplowitz N: Immune-mediated drug-induced liver disease. Clin Liver Dis 2002;6:755-774. Cohen SM, O'Connor AM, Hart J, Merel NH, Te HS: Autoimmune hepatitis associated with the use of black cohosh: a case study. Menopause 2004;11:575-577.

12 Björnsson E, Talwalkar J, Treeprasertsuk S, Kamath PS, Takahashi N, Sanderson S, Neuhauser M, Lindor K: Drug-induced autoimmune hepatitis: clinical characteristics and prognosis. Hepatology 2010;51: 2040-2048.

13 Manns MP, Czaja AJ, Gorham JD, Krawitt EL, Mieli-Vergani G, Vergani D, Vierling JM; American Association for the Study of Liver Diseases: Diagnosis and management of autoimmune hepatitis. Hepatology 2010;51:2193-2213.

14 Hennes EM, Zeniya M, Czaja AJ, Parés A, Dalekos GN, Krawitt EL, Bittencourt PL, Porta G, Boberg KM, Hofer H, Bianchi FB, Shibata M, Schramm C, Eisenmann de Torres B, Galle PR, McFarlane I, Dienes HP, Lohse AW; International Autoimmune Hepatitis Group: Simplified criteria for the diagnosis of autoimmune hepatitis. Hepatology 2008;48:169-176. 


\section{Case Reports in \\ Gastroenterology \\ Case Rep Gastroenterol 2017;11:23-28

Franco et al.: Black Cohosh Hepatotoxicity with Autoimmune Hepatitis Presentation

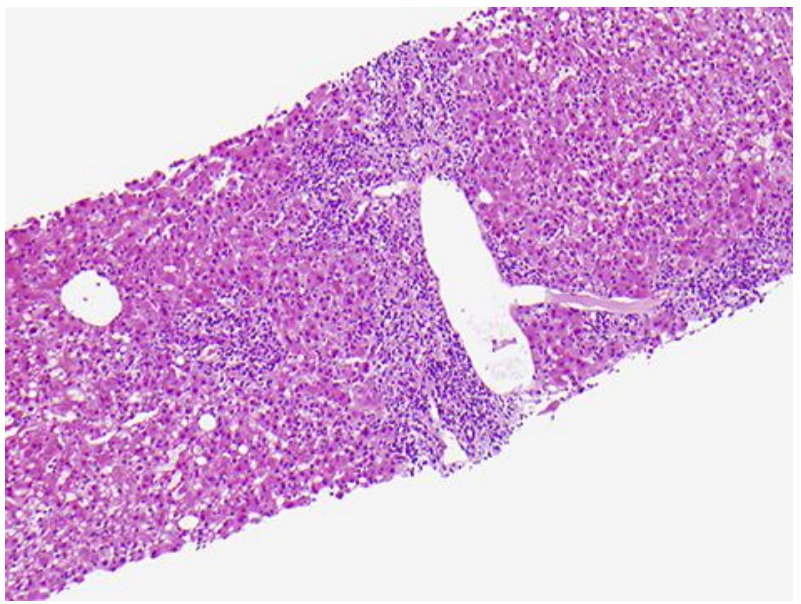

Fig. 1. Histologic sections show an prominent interface and lobular hepatitis. Hematoxylin and eosin. Original magnification, $\times 10$.

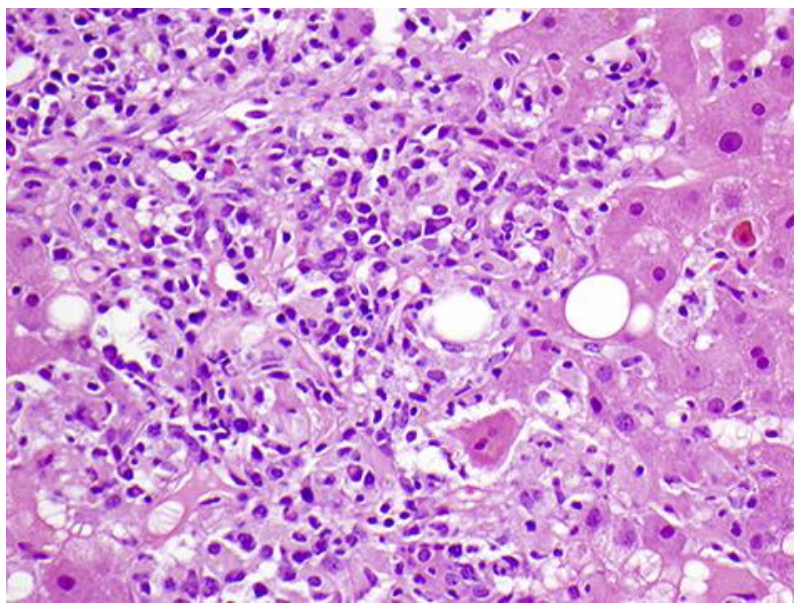

Fig. 2. Higher magnification highlights the plasma cell-rich infiltrate and single necrotic hepatocytes. A few eosinophils are also present, suggesting an element of drug-induced liver injury. Hematoxylin and eosin. Original magnification, $\times 40$. 
Franco et al.: Black Cohosh Hepatotoxicity with Autoimmune Hepatitis Presentation

Table 1. Laboratory values on the day of admission

Total bilirubin

Direct bilirubin

Anti-nuclear antibody

Anti-smooth muscle antibody

p-ANCA

Alkaline phosphatase

Alanine transaminase

Aspartate transaminase
$6.3 \mathrm{mg} / \mathrm{dL}$

$4.9 \mathrm{mg} / \mathrm{dL}$

1.7

Pos 1:80

Pos

$296 \mathrm{IU} / \mathrm{L}$

$2,385 \mathrm{IU} / \mathrm{L}$

$1,386 \mathrm{IU} / \mathrm{L}$

Table 2. Main test for hepatocellular injury

\begin{tabular}{lr}
\hline Main test criteria & Score \\
\hline Time to onset from beginning of the drug & +2 \\
Time to onset from cessation of the drug & +1 \\
Course of ALT after cessation of the drug & +3 \\
Risk factor - ethanol & 0 \\
Risk factor - age & +1 \\
Concomitant drug(s) & 0 \\
Search for nondrug causes & +2 \\
Previous information on hepatotoxicity of the drug & +1 \\
Response to readministration & 0 \\
\hline Total points & 10
\end{tabular}

ALT, alanine transaminase. 